\title{
Response of Apios americana to Nitrogen and Inoculation
}

\author{
D.H. Putnam ${ }^{1}$, G.H. Heichel ${ }^{2}$, and L.A. Field ${ }^{3}$ \\ Department of Agronomy and Plant Genetics, 411 Borlaug Hall, \\ University of Minnesota, St. Paul, MN 55108
}

Additional index words groundnut, potato bean, new crops, Bradyrhizobium japonicum, tuber yield, legume symbiosis, nitrogen fertilizers

\begin{abstract}
Apios americana Medikus (apios) is a wild tuberous legume with potential as a crop plant. Five apios accessions were grown in sand culture in two greenhouse experiments to examine the effect of $\mathbf{N}$ fertilization and inoculation with Bradyrhizobium japonicum on yield and plant characteristics. A common soybean B. japonicum strain (USDA76) was applied to plants watered with $0,50,100,200$, or $300 \mathrm{ppm} N$ solutions $\left(\mathrm{NH}_{4} \mathrm{NO}_{3}\right)$, plus a complete nutrient solution. At $\mathrm{O} \mathrm{N}$, total dry matter yield of noninoculated plants was only $\approx 30 \%$ of inoculated plants. However, total dry-matter yields of inoculated plants at $0 \mathrm{~N}$ were only $\approx 77 \%$ of plants supplemented with 50 or 100 ppm, indicating that inoculation alone was insufficient to meet the $\mathrm{N}$ needs of the plant. Tuber weight was increased by both $N$ and inoculation, but tuber weight decreased at $N$ concentrations $>\mathbf{1 0 0} \mathbf{p p m}$. Differences among plant accessions with regard to tuber fresh weight, harvest index, and modulation were found. These studies indicated that $\mathbf{N}$ fertilization maybe required to maximize tuber yields of apios.
\end{abstract}

Apios americana (groundnut or apios) is a wild legume native to the eastern half of North America that produces edible tubers, fleshy roots, and seeds. According to several records, the plant was gathered by various Native American tribes (Yarnell, 1964). It was consumed by the Pilgrims in their first years in America (Fernald and Kinsey, 1943) and probably brought to England as a New World potato by Sir Walter Raleigh (Schery, 1972). This history, in conjunction with its $\mathrm{N}$-fixing capabilities and the high protein and available carbohydrate content of the tuber (Walter et al., 1986; Wilson et al., 1987), has led to interest in apios as a possible new crop (Blackmon and Reynolds, 1986; Duke, 1987; Reed and Blackmon, 1985; Reynolds, et al., 1990; Vietmeyer, 1986). Several wildplant food enthusiasts have indicated a taste preference for apios over domesticated potato (Solanum tuberosum L.) (Gibbons, 1974; Harris, 1968; Medsger, 1939).

One of the reasons for interest in apios is

Received for publication 9 Apr. 1990. Joint contribution of the Minnesota Agr. Expt. Sta. (Sci. J. Series no. 18077), and the USDA-ARS. We thank Keith Henjum, Univ. of Minnesota, for helping with the greenhouse work, Peter Graham of the Microbiology Group, Soil Science Dept., Univ. of Minnesota, for producing the inoculum, H. Keyser, formerly of USDA-ARS of Beltsville, $M d$., for providing the B. japonicum strain, and W.J. Blackmon, Louisiana State Univ., for providing apios seed and tubers. The cost of publishing this paper was defrayed in part by the payment of page charges. Under postal regulations, this paper therefore must be hereby marked advertisement solely to indicate this fact.

'Assistant Professor.

${ }^{2}$ Formerly Plant Physiologist, Plant Science Research Unit, USDA-ARS, St. Paul, Minn. Current address: Head, Dept. of Agronomy, Univ. of Illinois, 1102 S. Goodwin, Urbana, IL 61801. ${ }^{3}$ Scientist. its unique role as an $\mathrm{N}_{2}$-fixing and tuberproducing plant (Putnam et al., 1990). Most tuber or root crops, such as potato, yam (Dioscorea sp.), or sweetpotato (Ipomoea batatas L. Lam.), require large inputs of $\mathrm{N}$ fertilizers for maximum economic yields. The introduction of a tuberous crop that fixes atmospheric $\mathrm{N}_{2}$ might reduce or eliminate this requirement. However, to our knowledge, there is no published information as to whether Rhizobium symbiosis is sufficient to supply the $\mathrm{N}$ needs of apios plants. Greenhouse studies were initiated to assess the importance of inoculation and additions of mineral $\mathrm{N}$ to plant growth, tuber yield, and nodulation of $A$. americana.

Greenhouse experiments were conducted using seed harvested from wild plants grown in Louisiana and North Carolina. The accession numbers and location of origin are provided in Table 2. Accessions chosen in the 2nd year differed slightly because of their potentially better adaptation to Minnesota. Accession 5 was added in 1988, and accessions 2 and 3 had insufficient seed for further experimentation in 1988. Sand was sterilized and placed in 5.8-liter pots, and surface-sterilized seed was planted in a randomized complete-block design with four replications. The trials were initiated on 3 Mar. 1987 (1987 experiment) and 12 Oct. 1987 (1988 experiment). The inoculated treatments received $10^{7}$ cells per plant of a $\mathrm{Bra}$ dyrhizobium japonicum soybean strain, USDA 76 , delivered on a peat base. After emergence, the sand was covered with $2 \mathrm{~cm}$ of perlite to reduce the opportunity for rhizobial cross-contamination and pots were separated by $30 \mathrm{~cm}$. Nitrogen (in the form of $\mathrm{NH}_{4} \mathrm{NO}_{3}$ ) at 0,100 , and $300 \mathrm{ppm} \mathrm{N}$ in 1987 and 0 , 50, 100, and $200 \mathrm{ppm} \mathrm{N}$ in 1988 was applied twice weekly through plastic access tubes. A Hoagland's complete nutrient solution (without $\mathrm{N}$ ), balanced to a $\mathrm{pH}$ of 6.8 , was 
Table 1. Plant characteristics ${ }^{2}$ of apios as affected by Nodes/plant inoculation and nitrogen (1988).

\begin{tabular}{|c|c|c|c|c|c|c|c|c|}
\hline \multirow[b]{2}{*}{$\begin{array}{c}\mathrm{N} \\
(\mathrm{ppm})\end{array}$} & \multicolumn{2}{|c|}{ Tuber } & \multirow{2}{*}{$\begin{array}{c}\text { Harvest } \\
\text { index } \\
(\%) \\
\end{array}$} & \multirow{2}{*}{$\begin{array}{c}\text { Plant } \\
\text { ht } \\
(\mathrm{cm})\end{array}$} & \multirow[b]{2}{*}{$\begin{array}{c}\text { Nodes/ } \\
\text { plant }\end{array}$} & \multirow[b]{2}{*}{$\begin{array}{c}\begin{array}{c}\text { Vigor } \\
\text { (rating) }^{\mathbf{x}}\end{array} \\
\end{array}$} & \multirow[b]{2}{*}{$\begin{array}{c}\text { Color } \\
\text { (rating) }^{\mathrm{w}}\end{array}$} & \multirow{2}{*}{$\begin{array}{c}\text { Leaf } \\
\text { length" } \\
(\mathrm{mm}) \\
\end{array}$} \\
\hline & $\begin{array}{l}\text { Fresh wt } \\
\text { (g/plant) }\end{array}$ & No./plant & & & & & & \\
\hline & \multicolumn{8}{|c|}{ Noninoculated } \\
\hline 0 & 11.4 & 2.8 & 35.5 & 69 & 13.0 & 1.7 & 1.7 & 32 \\
\hline 50 & 44.7 & 10.1 & 44.3 & 127 & 19.5 & 3.8 & 3.8 & 39 \\
\hline 100 & 35.5 & 10.8 & 37.9 & 118 & 18.6 & 3.6 & 3.6 & 40 \\
\hline 200 & 25.7 & 3.8 & 35.2 & 88 & 17.5 & 3.1 & 3.7 & 37 \\
\hline & \multicolumn{8}{|c|}{ Inoculated } \\
\hline 0 & 21.2 & 9.9 & 22.3 & 122 & 18.2 & 3.6 & 3.9 & 46 \\
\hline 50 & 31.2 & 8.7 & 24.3 & 129 & 20.0 & 4.3 & 4.6 & 43 \\
\hline 100 & 27.2 & 7.7 & 21.8 & 137 & 20.4 & 4.2 & 4.6 & 41 \\
\hline 200 & 29.0 & 6.9 & 30.8 & 89 & 16.8 & 3.0 & 3.7 & 42 \\
\hline \multicolumn{9}{|c|}{ Sources of variation } \\
\hline Nitrogen (N) & $* *$ & NS & Ns & $* *$ & $* *$ & $* *$ & $* *$ & NS \\
\hline $\mathrm{N}$ linear & NS & NS & NS & NS & NS & NS & ** & NS \\
\hline $\mathrm{N}$ quadratic & $* *$ & $* *$ & NS & $* *$ & $* *$ & $* *$ & $* *$ & NS \\
\hline $\mathrm{N}$ cubic & * & NS & NS & NS & NS & NS & NS & NS \\
\hline Access. (A) & $* *$ & $* *$ & $* *$ & $* *$ & $* *$ & $* *$ & $* *$ & $* *$ \\
\hline $\mathrm{N} \times \mathrm{A}$ & NS & NS & $*$ & NS & $*$ & NS & NS & * \\
\hline Inoc. (I) & NS & NS & ** & * & * & ** & $* *$ & ** \\
\hline $\mathrm{N} \times \mathrm{I}$ & $*$ & $*$ & NS & NS & $*$ & $* *$ & $* *$ & $* *$ \\
\hline$A \times I$ & NS & NS & NS & NS & NS & NS & NS & NS \\
\hline $\mathrm{N} \times \mathrm{A} \times \mathrm{I}$ & $*$ & NS & $*$ & NS & NS & NS & NS & NS \\
\hline
\end{tabular}

${ }^{2}$ Mean of three accessions grown in 1988.

YTuber dry weight as a percentage of total dry weight.

${ }^{x} 1-5$ scale, $5=$ most vigorous.

w1-5 scale, $5=$ darkest green.

"Leaf blade plus petiole.

NS.****Nonsignificant or significant at $P<0.05$ or $<0.01$, respectively, by ANOVA.

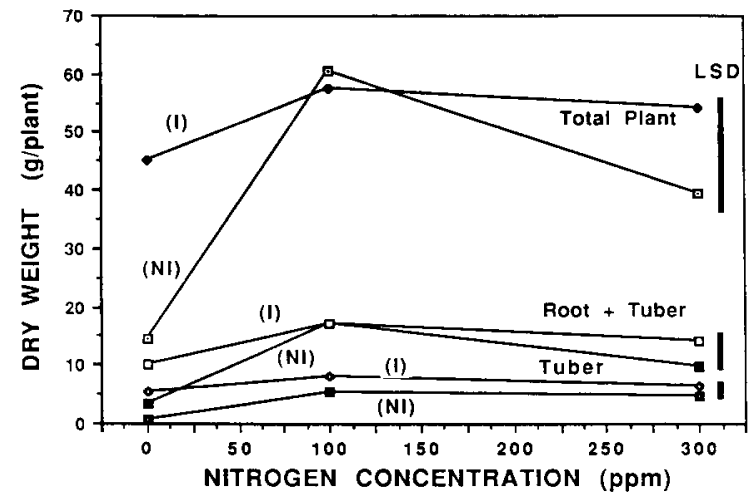

Fig. 1. Dry matter yield of $A$. americana in response to inoculation and application of $\mathrm{NH}_{4} \mathrm{NO}_{3}$ in 1987 (mean of four accessions). I = inoculated, NI = noninoculated control. (Significant effects at $P<0.05:$ Nitrogen, Inoculation, $\mathrm{N} \times \mathrm{I}$.)

also applied twice weekly through access tubes. Pots were leached to prevent salt accumulation. Supplemental fluorescent lightning was provided at a quantum flux density of $\approx 500 \mu \mathrm{mol} \cdot \mathrm{s}^{-1} \cdot \mathrm{m}^{-2}$ during an $18 / 6 \mathrm{~h}$ light/ dark cycle. The vines were trained on bamboo stakes. Plants were harvested on 5 Aug. 1987 and 7 June 1988, for the 1987 and 1988 experiments, respectively.

Data collected 2 weeks before harvest included plant height, vigor of shoots, color of plants, and number of shoots. At harvest, number of tubers, weight of tubers, root weight, viable nodule weight and number, and dry weight of herbage were recorded. Occasionally, fleshy roots were produced by plants, and these were included as tubers. Analysis of variance was applied to the data. The sums of squares for $\mathrm{N}$ were partitioned into orthogonal contrasts of linear, quadratic, and cubic effects. A Fisher's (pro- tected) least significant difference was used to separate accession means (Steel and Torrie, 1980).

Plant growth and total yield of noninoculated A. americana plants were $\approx 30 \%$ of those of inoculated treatments at zero N (Figs. 1 and 2). However, inoculation alone was insufficient to maximize total plant weight or tuber yields in either study. Through symbiosis with B. japonicum, apios produced total dry matter yields $\approx 77 \%$ of the yield from the optimum $\mathrm{N}$ plots (Figs. 1 and 2). Total plant and tuber dry matter yield increased with the addition of $\mathrm{N}$. However, high amounts of N, particularly 200 ppm N (Fig. 2 ), decreased yield and plants showed symptoms of ammonium toxicity.

Tuber production was affected more than total dry matter yields by the addition of $\mathrm{N}$. Fresh weight of tubers increased $21 \%$ and 47\% (1987 and 1988, respectively) with ad- ditions of 50 (1987) or 100 (1988) ppm $\mathrm{N}$ to the inoculated plants (Table 1). Data for 1987 were similar, but are not shown.

Noninoculated plants allocated $\approx 50 \%$ more dry matter to tubers than to shoots than inoculated plants as indicated by a higher harvest index at zero $\mathrm{N}$ (Table 1). Additions of $\mathrm{N}$ did not affect the harvest index or change the difference between inoculated or noninoculated plants. These results indicate a differential allocation of carbon between the inoculated and noninoculated plants that was independent of exogenous $\mathrm{N}$ supply. The lower allocation to tubers in the inoculated plants may represent reallocation of carbohydrate towards $\mathrm{N}_{2}$-fixation in the nodule, but more detailed studies would have to be conducted to verify this supposition.

Combined tuber and root dry-matter yield of inoculated treatments was higher than that of noninoculated treatments at zero N (Figs. 1 and 2). Fresh weight tuber yields of inoculated plants at zero $\mathrm{N}$ were $86 \%$ greater than those of noninoculated plants (Table 1). However, this difference between inoculation treatments was not consistent in the $\mathrm{N}$ treated pots. The difference between inoculated and noninoculated tuber yields, apparent at zero $\mathrm{N}$ in both years, was reversed at 50 or $100 \mathrm{ppm} \mathrm{N}$ in the 1988 study. The data indicated that for production of tubers, noninoculated plants were more responsive to additions of $\mathrm{N}$ than the inoculated plants.

The increase in tuber yield with 50 or 100 ppm added $\mathrm{N}$ was accompanied by increases in tuber count only for noninoculated plants (Table 1). Tuber count declined at high concentrations of $\mathrm{N}$ in the noninoculated treatments.

Plant height, node count, leaf length, color, 


\begin{tabular}{|c|c|c|c|c|c|c|c|c|c|c|c|}
\hline \multirow[b]{2}{*}{ Accession } & \multirow[b]{2}{*}{ Origin } & \multicolumn{2}{|c|}{ Total dry wt } & \multicolumn{2}{|c|}{ Tuber fresh wt } & \multicolumn{2}{|c|}{ Harvest index ${ }^{y}$} & \multicolumn{2}{|c|}{$\begin{array}{c}\text { Nodule fresh } \\
\text { wt }\end{array}$} & \multicolumn{2}{|c|}{ Nodules/plant } \\
\hline & & 1987 & 1988 & 1988 & 1988 & 1987 & 1988 & 1987 & 1988 & 1987 & 1988 \\
\hline & & \multicolumn{4}{|c|}{ g/plant } & \multicolumn{6}{|c|}{ mg/plant } \\
\hline 1. XXXVI E3 & $\begin{array}{l}\text { Pointe Coupee } \\
\text { Parish, La. }\end{array}$ & 43.4 & 41.4 & 23.0 & 38.7 & 14.2 & 30.7 & 2.7 & 2.6 & 40 & 57 \\
\hline $\begin{array}{l}\text { 2. X1 F1 } \\
\text { 3. LXVIII EI }\end{array}$ & $\begin{array}{l}\text { Iberville } \\
\text { Parish, La. } \\
\text { Iberville }\end{array}$ & 41.1 & $\cdots$ & 15.2 & $\cdots$ & 9.3 & $\cdots$ & 1.9 & $\cdots$ & 21 & $\cdots$ \\
\hline 4. XXXVII & $\begin{array}{l}\text { Parish, La. } \\
\text { Iberville }\end{array}$ & 50.4 & --- & 13.8 & $-\cdots$ & 9.2 & $\cdots$ & 2.6 & -- & 27 & --- \\
\hline 5. XIXA2 & $\begin{array}{l}\text { Parish, La. } \\
\text { Pleasant Plain, }\end{array}$ & 43.4 & 36.9 & 11.3 & 24.6 & 8.2 & 26.1 & 2.3 & 2.5 & 46 & 75 \\
\hline & N.C. & $\cdots$ & 23.9 & -- & 21.3 & --- & 36.5 & -- & 1.1 & --- & 30 \\
\hline $\operatorname{LSD}(P=0.05)$ & & NS & 3.5 & 3.9 & 4.6 & 2.5 & 5.2 & NS & 0.4 & NS & 14 \\
\hline
\end{tabular}

${ }^{2}$ Mean of $\mathrm{N}$ treatments.

${ }^{y}$ Tuber dry weight as a percentage of total dry weight.

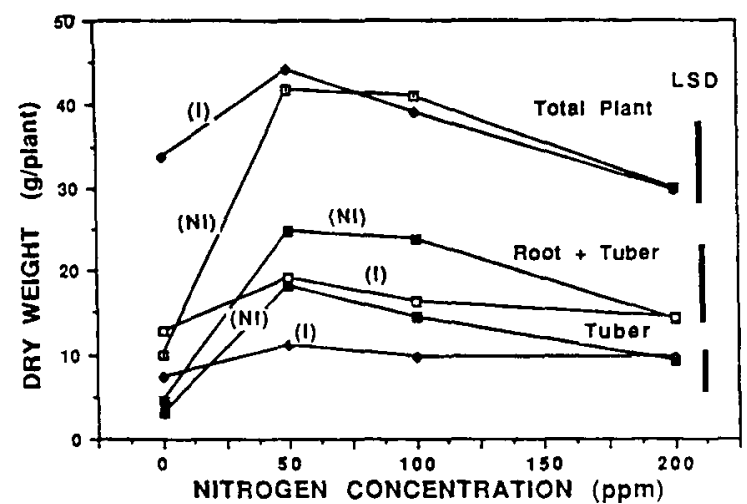

Fig. 2. Dry matter yield of A. americana in response to inoculation and application of $\mathrm{NH}_{4} \mathrm{NO}_{3}$ in 1988 (mean of three accessions). I = inoculated, NI = noninoculated control. (Significant effects at $P<0.05$; Nitrogen, Inoculation, variety, $\mathrm{N} \times \mathrm{I}$ )

and vigor rating (Table 1) were increased by inoculation and by $\mathrm{N}$ in a pattern similar to total dry matter production (Fig. 2).

There were differences among accessions for tuber fresh weight, total dry weight, harvest index, and nodule fresh weight (Table 2 ). These apios accessions, obtained from the wild, generally exhibited a high degree of variability (Blackmon and Reynolds, 1986). However, the accession XXXVI E3 from Louisiana was more vigorous and produced a significantly greater fresh weight of tubers in both years than other accessions. Harvest index also tended to be high in this line. This line also performed well in field trials (Putnam et al., 1990).

If apios is grown in an agronomic or a horticultural setting it maybe planted by seed or by tuber. If tubers are used, rhizobial symbiants likely would accompany the clones, and if the tubers are stored at low temperatures, these Rhizobium may remain viable. Inoculation is likely to be more important in seed-planted apios. However, the fact that apios was well nodulated with a common soybean strain in this study and that others have reported modulation with rhizobia obtained from cowpeas (Allen and Allen, 1981) suggests that under agronomic conditions, modulation should not be a severe problem. We have observed nodules on plants growing without any controlled inoculation in experimental plots and on plants collected from the wild in Minnesota.

\section{Literature Cited}

Allen, D.N. and E.K. Allen. 1981. Apios. The Leguminosae-A source book of characteristics, uses and modulation. Univ. of Wisconsin Press, Madison, Wis. p. 56-57.

Blackmon, W.J. and B.D. Reynolds. 1986. The crop potential of Apios americana — preliminary evaluations. HortScience 21:1334-1336.

Duke, J.A. 1987. Help rediscover an American vegetable: Apios. Organic Gardening. Jan p. 98101 .
Fernald, M.L. and A.C. Kinsey. 1943. Edible wild plants of eastern North America. Eldewild Press, New York. p. 252-255.

Gibbons, E. 1974. Stalking the wild asparagus. D. McKay Co., New York.

Harris, B.C.. 1968. Eat the weeds. Barre Publications, Barre, Mass. p. 125-127.

Medsger, O.P. 1939. Edible wild plants. Macmillan, New York. p. 187-188.

Putnam, D.H., L. Field, and G.H. Heichel. 1990. Inoculation, nitrogen, and cultivar effects on modulation and tuber yield of Apios americana p. 444. In: J. Janick and J.E. Simon (eds.). Advances in new crops. Timber Press, Portland, Ore.

Reed, M.J. and W.J. Blackmon. 1985. Observations on the potential of Apios americana as a food crop. HortScience 20:557.

Reynolds, B.D., W.J. Blackmon, E. Wickremesinhe, M.H, Wells, and R.J. Constantin. 1990. Domestication of Apios americana, p. 436442. In: J. Janick and J. Simon (eds.). Advances in new crops. Timber Press, Portland, Ore.

Schery, R.W. 1972. Plants for man. 2nd ed. Prentice Hall, Englewood Cliffs, N.J.

Steel, R.G.D. and J.H. Torrie. 1980. Principles and procedures of statistics, a biometrical approach. 2nd ed. McGraw-Hill, New York.

Vietmeyer, N. 1986. Lesser-known plants of potential use in agriculture and forestry. Science 232:1379-1384.

Walter, W. M., E.M. Croom, G.L. Catignani, and W.C. Thresher. 1986. Compositional study of Apios princeana tubers. J. Agr. Food Chem. 34:39-41.

Wilson, P.W., F.J. Pichardo, J.A. Livzzo, W.J. Blackmon, and B.D. Reynolds. 1987. Amino acids in the American groundnut (Apios americana). J. Food Sci. 52(1):224-225.

Yarnell, R.A. 1964. Aboriginal relationships between culture and plant life in the Upper Great Lakes region. Anthropological Papers. no. 23, Museum of Anthropology, Univ. of Mich., Ann Arbor. 